\title{
EFFECTS OF SALINITY ON THE GROWTH RATE, MORPHOLOGY AND WATER CONTENT OF SOME BRAZILIAN RED ALGAE OF ECONOMIC IMPORTANCE
}

\section{EFECTOS DE LA SALINIDAD EN LA TASA DE CRECIMIENTO, MORFOLOGIA Y CONTENIDO DE AGUA DE ALGUNAS ALGAS ROJAS BRASILEÑAS DE IMPORTANCIA ECONOMICA}

\author{
Nair S. Yokoya ${ }^{1}$ \\ Eurico C. de Oliveira ${ }^{2}$ \\ 1 Instituto de Botanica \\ Secretaria do Meio Ambiente \\ C. Postal 4005, 01051, Sao Paulo, Brasil \\ 2 Instituto de Biociencias e Centro de Biologia Marinha \\ Universidade de Sao Paulo \\ C. Postal 11.461, 01000, Sao Paulo, Brasil
}

Recibido en mayo de 1991; aceptado en octubre de 1991

\begin{abstract}
The growth rate, morphology and water content of six species of Brazilian red algae of economic importance were studied under various salinities. The study comprises three agarophytic (Gracilaria aff. vemucosa, Gracilaria sp. and Pterocladia capillacea), and three carrageenophytic algae (Meristiella echinocarpa, Hypnea comuta and $H$. musciformis), subjected to salinities from 5 to $60 \%$ oo. All species tolerated, for the period and conditions described, a much broader range of salinities than they usually face in their habitats. All species were more tolerant to salinities above $30 \%$ than below this value, with maximum growth occurring between $25-40 \%$ oo. Water content at the end of the experiments varied with the species, with an inverse relation in salinities above $40 \%$. Highest salinity values reduced branching, and lowest salinities lead to thalli bleaching. The results offer guidelines for the selection of potential areas with more adequate salinity regimes for the cultivation of the species studied.
\end{abstract}

\section{RESUMEN}

Se realizaron experimentos a diferentes salinidades para estudiar la tasa de crecimiento, morfología y contenido de agua en algas rojas brasileñas de importancia económica. El estudio comprende tres algas agarofíticas (Gracilaria aff. vemucosa, Gracilaria sp. y Pterocladia capillacea), y tres algas carragenofíticas (Meristiella echinocarpa, Hypnea cornuta y $\mathrm{H}$. musciformis), las cuales fueron sometidas a salinidades desde 5 hasta $60 \%$. Todas las especies toleraron un intervalo mucho más amplio de salinidades para el períodoy condiciones descritas, al que generalmente tienen en sus respectivos habitats. Las especies resultaron ser más tolerantes a salinidades por encima de $30 \%$ que por debajo de este valor, presentando un crecimiento máximo entre $25-40 \%$. El contenido de agua en las especies varió al final de los experimentos, con una relación inversa en salinidades por encima de $40 \%$. Los valores más altos de salinidad redujeron la bifurcación de éstas, y los valores de salinidad más bajos produjeron decoloración del talo. Los resultados de este estudio permiten elegir zonas de potencial para el cultivo de las especies estudiadas bajo regímenes de salinidad adecuados. 


\section{INTRODUCTION}

Affecting osmoregulation and ion concentration, salinity interferes with biological systems and processes in many ways. It is considered an important environmental factor controlling various aspects of the biology and ecology of benthic marine algae.

Although most species of "marine algae" have broad toleration to salinity (e.g. Biebl, 1937; Gessner and Schramm, 1971), this parameter certainly has a key role in the distribution of algae along gradients such as in estuaries, mangals and coastal lagoons (e.g. Conover, 1964; Oliveira, 1984; King and Wheeler, 1985).

The effects of salinity on the benthic algae distribution have been documented by several authors (e.g. Sundene, 1953; Druehl, 1967; Munda, 1978; Khfaji and Norton, 1979), as well as its effect on growth (e.g. Nygren, 1970; Ogata and Schramm, 1971; Bird et al., 1979; Bird and McLachlan, 1986) and morphology (Burns and Mathieson, 1972; Mathieson and Burns, 1975; Reed and Russel, 1978; Zablackis, 1987). Most of these studies, however, deal with cold water species rather than with tropical ones.

Considering the large interest on commercial red algae in Brazil, we are studying the biology of several species to provide basic knowledge for the selection of places and species suitable for cultivation. In this paper we report on some effects of salinity on six species of red algae from Brazil.

\section{MATERIALS AND METHODS}

We selected three species of agarophytic and three carrageenophytic algae from different places in Brazil, isolated in unialgal cultures from spores or apical segments (Table 1). Conditions for incubation of stock cultures were: temperature $23( \pm 3)^{\circ} \mathrm{C}$, $35-40 \mu \mathrm{mol} \mathrm{m}^{-2} \mathrm{~s}^{-1}$ photon flux density, provided by cool-white fluorescent lamps (Phillips) on a light/dark cycle of $16 / 8$ hours, and salinity of $32( \pm 2) \%$. These conditions were chosen after some previous experiments, and they proved to be adequate to keep most of the species growing well in vitro. The cultures were kept in half-strength Provasoli's enriched seawater (PES) as specified by McLachlan (1973), and air bubbled every

\section{INTRODUCCION}

La salinidad es un factor que interviene en los sistemas y procesos biológicos en diversas formas, afectando la osmoregulación y la concentración de iones. Esta es considerada un factor ambiental muy importante por controlar varios aspectos de la biología y ecología de las algas marinas.

Aun cuando la mayoría de las algas marinas tienen alta tolerancia a la salinidad (e.g. Biebl, 1937; Gessner and Schramm, 1971), este parámetro juega un papel determinante en la distribución de las algas en diversos ambientes tales como estuarios, manglares y lagunas costeras (e.g. Conover, 1964; Oliveira, 1984; King y Wheeler, 1985).

Los efectos de la salinidad en la distribución de las algas bentónicas han sido documentados por varios autores (e.g. Sundene, 1953; Druehl, 1967; Munda, 1978; Khfaji y Norton, 1979), así como los efectos de ésta sobre el crecimiento (e.g. Nygren, 1970; Ogata y Schramm, 1971; Bird et al., 1979; Bird y McLachlan, 1986) y la morfología (Burns y Mathieson, 1972; Mathieson y Burns, 1975; Reed y Russel, 1978; Zablackis, 1987). Sin embargo, la mayoría de estos estudios están relacionados más bien con especies de aguas frías que con especies tropicales.

Debido a que existe un gran interés comercial por las algas rojas en Brasil, este estudio provee un conocimiento básico sobre la biología de varias especies, con el fin de poder elegir sitios que sean aptos para el cultivo de éstas. En este estudio se reportan algunos efectos de la salinidad en seis especies de algas rojas de Brasil.

\section{MATERIALES Y METODOS}

Se seleccionaron tres especies de algas agarofiticas y tres de algas carragenofiticas provenientes de diferentes sitios en Brasil. De cada una de éstas, fueron aislados esporas o segmentos apicales para cultivo (Tabla 1). Las condiciones para incubación de estos cultivos fueron bajo temperatura de $23( \pm 3)^{\circ} \mathrm{C}$, con una densidad de flujo de fotones de $35-40 \mu \mathrm{mol} \mathrm{m}^{-2} \mathrm{~s}^{-1}$ el cual fue provisto por lámparas fluorescentes (Phillips) en un ciclo de luz/obscuridad de $16 / 8$ horas, y bajo una salinidad de $32( \pm 2) \%$. Estas condiciones se eligieron con base en experimentos previos, y 
Table 1. Location and collecting dates of the studied species.

Tabla 1. Lugar y fecha de colecta de las especies estudiadas.

\begin{tabular}{llll}
\hline Species & Locality & Date & $\begin{array}{l}\text { Cultures initiated } \\
\text { from }\end{array}$ \\
\hline $\begin{array}{l}\text { Gracilaria aff. ventucosa } \\
\text { (Huds.) Papenf. }\end{array}$ & Ubatuba, SP & Aug. 86 & Spores \\
$\begin{array}{l}\text { Gracilaria sp. } \\
\begin{array}{l}\text { Hypnea comuta } \\
\text { (Lam.) J. Ag. }\end{array}\end{array}$ & Lagoa de Araruama, RJ & Nov. 87 & Spores \\
$\begin{array}{l}\text { Iypnea muscifomis } \\
\text { (Wulf.) Lam. }\end{array}$ & Lagoa de Araruama, RJ & Oct. 85 & Apical segments \\
$\begin{array}{l}\text { Meristiella echinocaipa } \\
\text { (Aresch.) Cheney }\end{array}$ & Lecife, PE & Mar. 86 & Apical segments \\
$\begin{array}{l}\text { Pterocladia capillacea } \\
\text { (Gmelin) Born. et Thur. }\end{array}$ & Ubatuba, SP & Nov. 84 & Spores \\
\hline
\end{tabular}

three hours, for three hours. Germanium dioxide $\left(1 \mathrm{mg} . \mathrm{l}^{-1}\right)$ was used to suppress diatom growth when necessary.

The salinities tested ranged from 5 to $60 \%$ (up to $80 \%$ for Gracilaria sp.) with intervals of $5 \%$. Seawater $32( \pm 2) \%$, was filtered $(0.45 \mu \mathrm{m})$, sterilized and concentrated by freezing. Gradual melting and mixtures provided all the desired salinities. The final salinity was checked with a calibrated refractometer (American Optical).

Equal size apical segments were cut from vegetative tetrasporophytes from the stock cultures. Initial inoculum for each replicate with four $10 \mathrm{~mm}$ length apical segments were inoculated into $250 \mathrm{ml}$ conical flasks containing $200 \mathrm{ml}$ of full-strength PES, and kept at the described conditions. Three replicates were observed for each treatment.

Media renewal, weighing, and general observations were made weekly. Before weighing, segments were blotted with bibulous paper to remove excess water. Growth was determined by fresh weight variations. Growth rate $(k)$ was calculated as:

$$
k=\frac{\log _{2}\left(I_{1} f \cdot I_{1} O^{-1}\right)}{t}
$$

se comprobóque son las adecuadas para que la mayoría de las especies crezcan bien in vitro. Los cultivos se mantuvieron en agua de mar enriquecida de fuerza media de Provasoli (PES), según lo especificado por McLachlan (1973), y fueron bombeadospor aire cada tres horas, por un período de tres horas. Se utilizó dióxido de germanio $\left(1 \mathrm{mg} \cdot \mathrm{l}^{-1}\right)$ para evitar el crecimiento de diatomeas.

Se probaron diferentes salinidades en un intervalo de 5 a $60 \%$ oo (hasta $80 \%$ oo para Gracilaria sp.) con intervalos de 5\%/00. El procedimiento para el agua de mar con salinidad de $32( \pm 2) \%$, fue filtración $(0.45 \mu \mathrm{m})$, esterilización y concentración por congelación. Se llevó a cabo un mezclado gradual para poder proveer todas las salinidades deseadas, $y$ la salinidad final fue checada con un refractómetro calibrado (American Optical).

Los segmentos de éstas fueron cortados al mismo tamaño, provenientes de tetrasporofitas vegetativas de las reservas en cultivo. Se inocularon en matraces cónicos (conteniendo $200 \mathrm{ml}$ de PES de fuerza total) para cada réplica cuatro segmentos apicales de $10 \mathrm{~mm}$ de longitud, y se guardaron bajo las condiciones descritas. Para cada uno de los tratamientos se observaron tres réplicas. 
where: $W o=$ initial fresh weight; $W f=$ final fresh weight; $t=$ time in days.

For dry weight determinations the algae were placed in an oven at $60^{\circ} \mathrm{C}$ for 48 hours, and cooled in a desiccator for two hours before weighing.

Analysis of variance with repeated measures was conducted on the data of growth rate $(k)$ and percentage of water content.

\section{RESULTS}

Most species tolerated a broad range of salinities, being less sensitive to the higher salinities than to the lower ones, if we consider $35 \%$ as normal value. Maximum growth, for all species, occurred in salinities between 25 and $40 \%$ oo (Figs. 1 to 7; Tables 2 and 3).

Pterocladia capillacea was the most tolerant species, although we did not test it in salinities above 50\% Hypnea muscifomis was the most sensitive one (Figs. 4 and 7). With the exception of $H$. muscifomis, that died in salinities above $55 \%$, the higher salinities tested were not lethal to the other species, despite a significant reduction of the growth rate (Fig. 7; Table 2). On the other hand, most species were very sensitive to lower salinities (below $15 \%$ ) , bleaching and dying within a few days. The lethal salinities varied with the species. Hypnea comula and H. muscifomis did not withstand salinities below 20\% (Figs. 3 and 4). Salinities below 15\%/00 were lethal to Meristiella echinocarpa (Fig. 5). Gracilaria aff. vemucosa and Gracilaria sp. tolerated salinities down to $10 \%$ (Figs. 1 and 2), but showed bleaching and necrotic zones at the end of the experiments (Figs. 8 and 9). Those two species behaved similarly, tolerating salinities from 10 to $60 \%$. However, Gracilaria sp. showed a higher growth rate $(k)$ in the higher salinities, i.e. above $35 \%$, while $G$. aff. vemucosa had higher $k$ below that value (Table 2).

A comparison of the growth rates of all the species shows that Pterocladia capillacea has the lowest $k$. On the other hand, Hypnea comuta showed the highest $k(0.389)$, equal to a doubling time of 2.6 days, although very variable (Fig. 7 ).
Semanalmente, se llevaron a cabo observaciones generales, se pesaron y hubo renovación del medio. Antes de pesar los ejemplares, éstos fueron secados con papel absorbente para remover el exceso de agua. El crecimiento que se dio en éstos fue determinado por las variaciones que se dieron en el peso fresco. La tasa de crecimiento $(k)$ se calculó de la siguiente forma:

$$
k=\frac{\log _{2}\left(V^{\prime} f \cdot V^{-1}\right)}{t}
$$

donde: $W o=$ peso fresco inicial; $W f=$ peso fresco final; $\boldsymbol{t}=$ tiempo en días.

Para la determinación del peso seco de las algas, éstas fueron colocadas en un horno a $60^{\circ} \mathrm{C}$ durante 48 horas, y fueron enfriadas en un desecador por dos horas antes de ser pesadas.

Se hicieron varias mediciones sobre 10 anterior para poder llevar a cabo el análisis de varianza de los datos de la tasa de crecimiento (k) y el porcentaje de contenido de agua.

\section{RESULTADOS}

La mayoría de las especies toleraron un amplio intervalo de salinidades, siendo menos sensibles a las altas salinidades que a las más bajas, considerando $35 \%$ como el valor normal. El máximo crecimiento, para todas las especies bajo estudio, ocurrió bajo salinidades entre 25 y $40 \%$ oo (Figs. 1 a 7; Tablas 2 y 3 ).

La más resistente de las especies resultó ser Pterocladia capillacea, aun cuando ésta no fue sometida a salinidades por encima de $50 \%$ (Figs. 6 y 7), mientras que Hypnea muscifomis fue la más sensible de todas (Figs. 4 y 7). Con excepción de $H$. muscifomis, que murió en salinidades superiores a $55 \%$, oo, las salinidades mayores no fueron letales para las otras especies, a pesar de que existió una reducción significativa en la tasa de crecimiento (Fig. 7; Tabla 2). Por otro lado, la mayoría de las especies fueron muy sensibles a salinidades bajas (menos de 15\% \%o), decolorándose y muriendo unos cuantos días después. Las salinidades letales variaron para cada especie. Hypnea comusa y H. muscifomis no toleraron salinidades por debajo de 20\% 100 (Figs. 3 y 4) Para Meristiella echinocarpa, la salinidad letal 

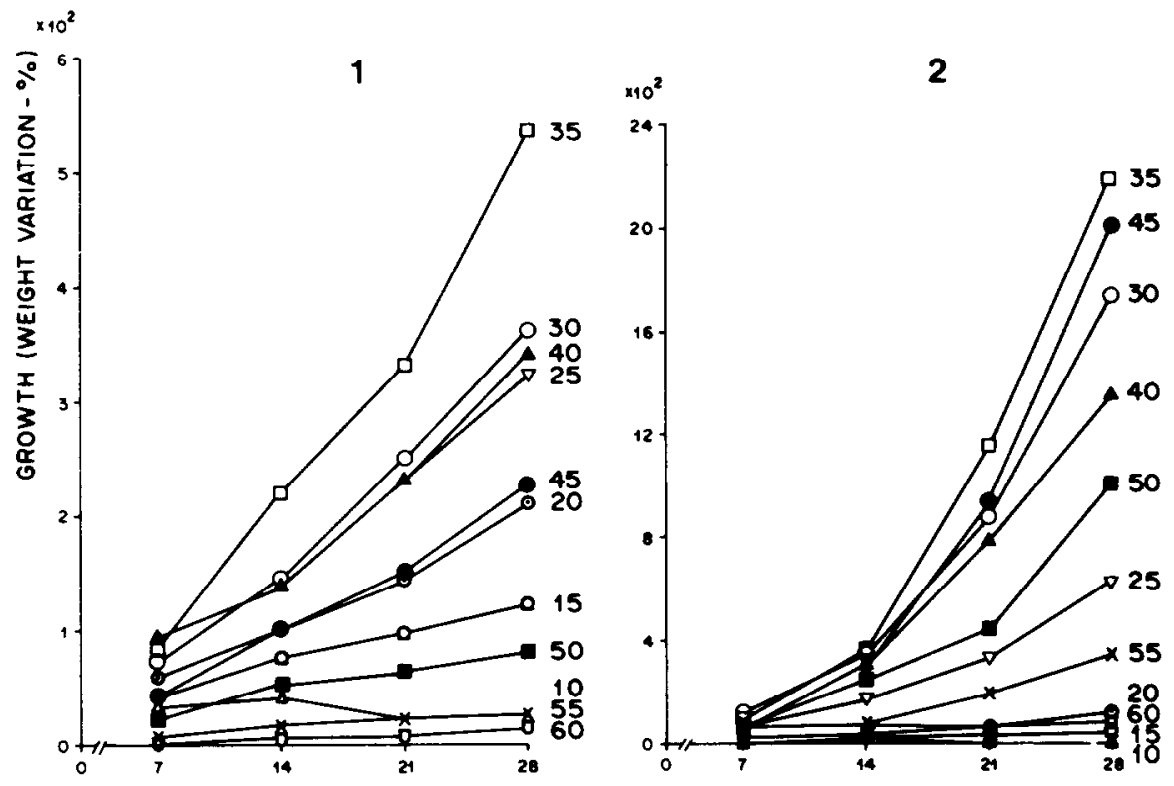

Figures 1-2. Growth curves based on weight variation $\left(c=(W f-W o) \cdot W^{-1} \cdot 100\right)$ of plants incubated in different salinities. $W f=$ final fresh weight, $W_{0}$ - initial fresh weight. (1) Gracilaria aff. vemucosa, (2) Gracilaria sp.

Figuras 1-2. Curvas de crecimiento basadas en la variación del peso $\left(c \cdot c=(W f-W o) . W_{O}{ }^{-1} \cdot 100\right)$ de plantas incubadas en diferentes salinidades. $W f-$ peso fresco final, $W_{o}=$ peso fresco inicial. (1) Gracilaria aff. venucosa, (2) Gracilaria sp.

The percentage of water content in the thalli, incubated in different salinities, is shown for four of the species studied (Table 3). The water content in the salinity of $35 \%$ varied from 85.7 to $90.0 \%$ of the fresh weight. The relative proportion of water decreases significantly in salinities higher than $40 \%$, and increases in salinities between 20 to $40 \%$. However, significant differences in water content were not observed on plants incubated in $30 \%$ to $G$. aff. vemucosa, $30-40 \%$ to Gracilaria sp. and $M$. echinocarpa, and $30-50 \%$ oo to $H$. comuta, when compared with the value obtained at $35 \%$ (Table 3).

Salinity not only affected growth rate and water content, but also plant morphology, as shown in Figures 8 and 9. Higher salinities reduced branch length but pigmentation was not affected, while lower salinities did not affect branching, except in the extreme values, and caused bleaching. se dio por debajo de $15 \%$ (Fig. 5), y Gracilaria aff. vemucosa y Gracilaria sp. toleraron salinidades hasta de $10 \%$ (Figs. 1 y 2), pero al final del experimento éstas mostraron decoloración y presencia de zonas necróticas (Figs. 8 y 9). Estas dos especies tuvieron un comportamiento muy similar, tolerando salinidades entre 10 y $60 \% \%$. Sin embargo, Gracilaria sp. mostró una tasa de crecimiento $(k)$ más alta bajo salinidades mayores, i.e. por encima de $35 \%$ oo, mientras que $G$. aff. vemucosa tuvo una $k$ más alta por debajo de ese valor (Tabla 2).

Pterocladia capillacea mostró ser la especie con más bajo valor de $k$, e Hypnea comuta mostró tener los más altos valores (0.389). lo que equivale a un período de duplicación de 2.6 días, aunque éste puede ser variable (Fig. 7).

La Tabla 3 muestra el porcentaje de contenido de agua en el talo, incubado bajo diferentes salinidades, para cuatro de las 

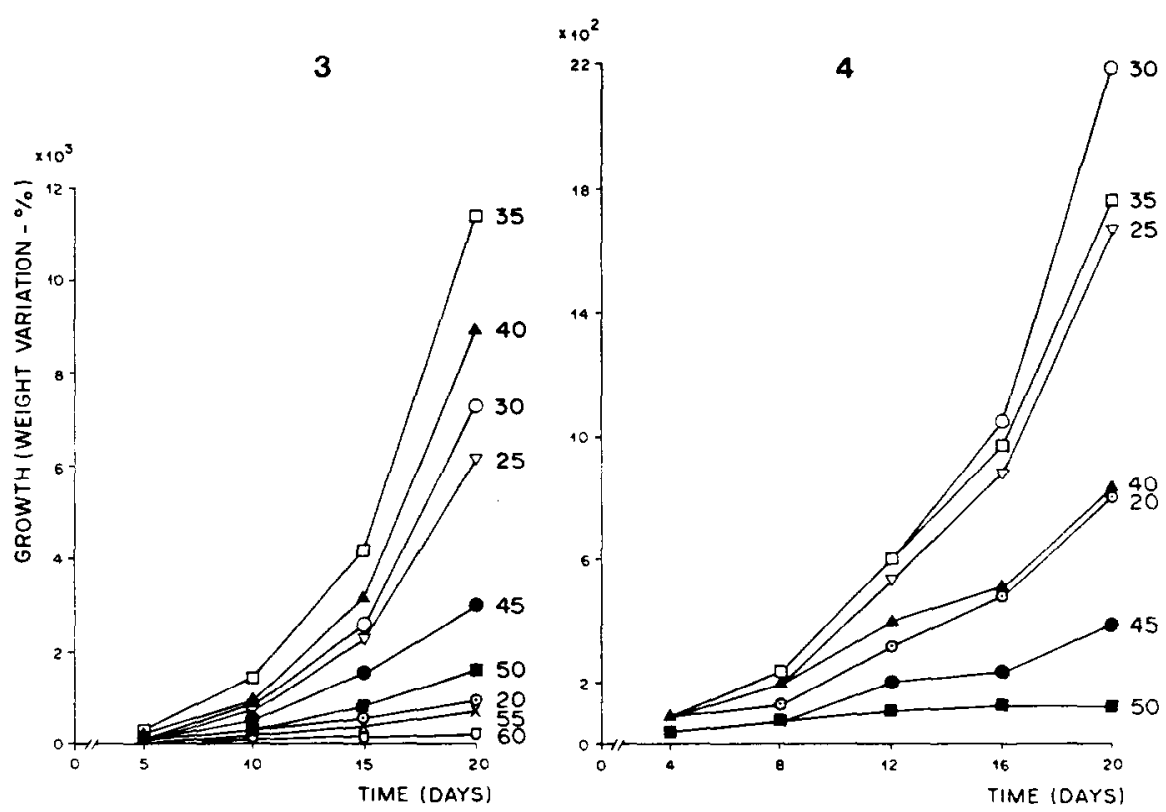

Figures 3-4. Growth curves based on weight variation $\left(\%=(W f-W o) . W o^{-1} .100\right)$ of plants incubated in different salinities. $W f=$ final fresh weight, $W o=$ initial fresh weight. (3) Hypnea comuta, (4) Hypnea muscifonis.

Figuras 3-4. Curvas de crecimiento basadas en la variación del peso $\left(\%=(W f-W o) \cdot W^{-1} .100\right)$ de plantas incubadas en diferentes salinidades. $W f=$ peso fresco final, $W o=$ peso fresco inicial . (3) Hypnea comuta, (4) Hypnea muscifomis.

\section{DISCUSSION}

The species studied presented a broad tolerance to salinity variations under laboratory conditions. Nevertheless, salinity variation interferes significantly with the growth rates as shown in Table 3 . These results certainly reflect their natural distribution. All the species studied, with the exception of Meristiella echinocarpa, can be found in the intertidal zone, therefore, subject to variable periods of emersion and consequently to broader variation of environmental factors. Similar conclusions were already reached by others, since Biebl (1937).

The euryhalinity of Gracilaria species was well documented by Causey et al. (1946), Stokke (1957), Simonetti et al. (1970), Muñoz et al. (1984) and Bird and MeLachlan (1986). Causey et al. (1946) determined maximum growth of $G$. vemucosa in salinities from 25 to $35 \%$ and Bird and McLachlan (1986) ob- especies estudiadas. El contenido de agua en salinidades de 35\% varió desde 85.7 a $90.0 \%$ del peso fresco. La proporción relativa de agua decreció significativamente en salinidades superiores a $40 \%$, y se incrementó en salinidades entre 20 y $40 \%$. Sin embargo, no se pudieron observar diferencias significativas en cuanto al contenido de agua en los ejemplares incubados a $30 \%$ para $G$. aff, verrucosa, 30-40\% para Gracilaria sp. y $M$. echinocarpa, y $30-50 \%$ para $H$. comuta, cuando éstos fueron comparados con el valor obtenido a 35\% $\%$ (Tabla 3).

La salinidad no solo afectó la tasa de crecimiento y el contenido de agua de los ejemplares, sino también la morfología de éstos, como se puede observar en las Figuras 8 y 9. La longitud de las hojas se vio afectada por altas salinidades pero no fue afectada la pigmentación, mientras que las salinidades bajas no afectaron la bifurcación, excepto en los valores extremos, pero si causaron decoloración. 

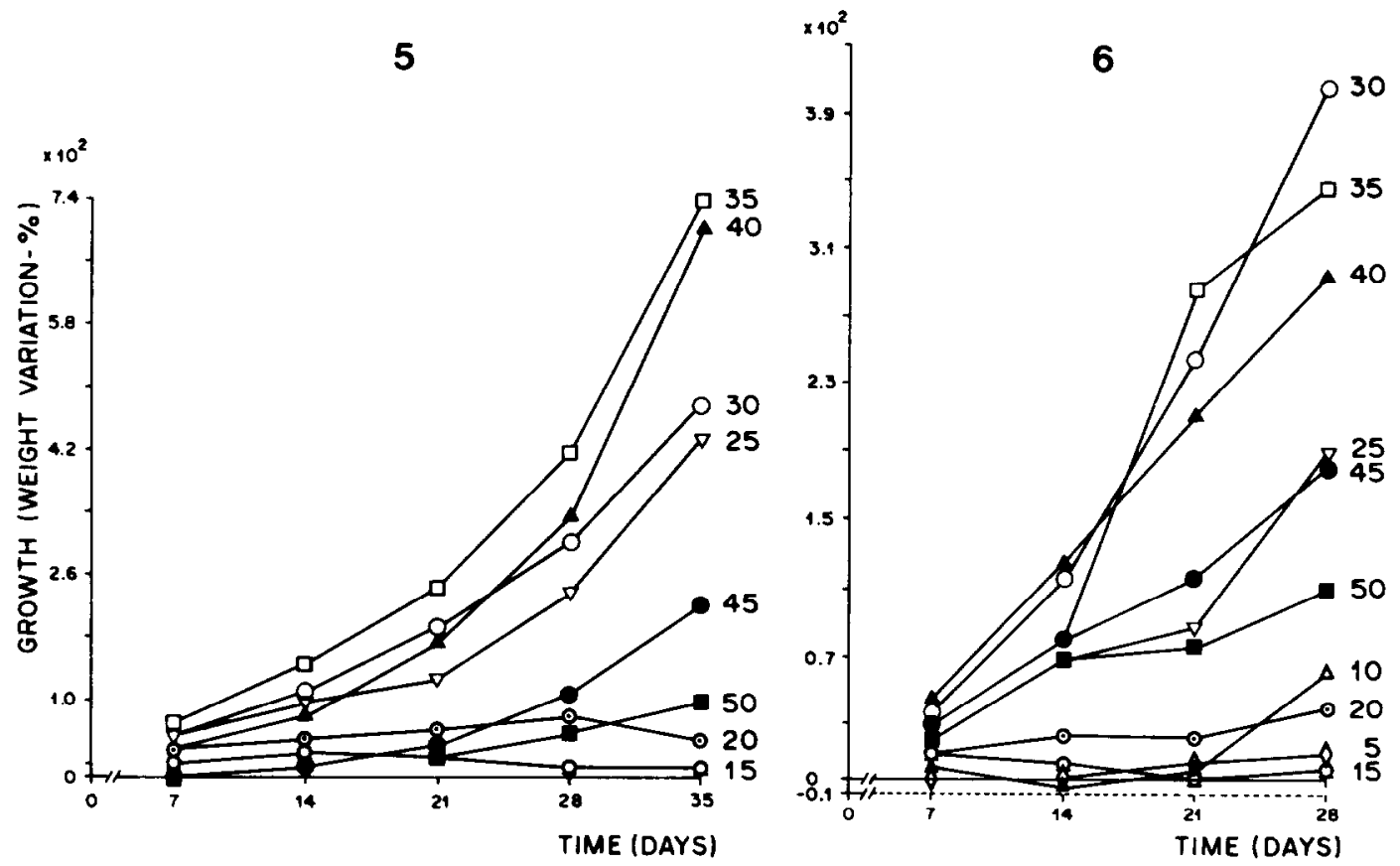

Figures 5-6. Growth curves based on weight variation $\left(\mathscr{F}=\left(W f-W_{O}\right) . W_{O}^{-1} .100\right)$ of plants incubated in different salinitics. $W f=$ final fresh weight, $W o=$ initial fresh weight. (5) Meristiella echinocapa, (6) Pterocladia capillacea.

Figuras 5-6. Curvas de crecimiento basadas en la variación del peso $\left(c / \%=(W f-W o) \cdot W o^{-1} .100\right)$ de plantas incubadas en diferentes silinidades. $W f=$ peso fresco final, $W o=$ peso fresco inicial (5) Meristiclla echinocapa, (6) Pterodadia capillacea.

served that 15 to $38 \%$ was the usual maximum growth range for several species of Gracilaria. These results agree with ours for $G$. aff. venucosa, presenting maximum growth in salinities from 25 to $40 \%$ oo. Gracilaria sp. showed relatively higher growth rates in salinities above $35 \%$, while in $G$. aff. vemucosa growth rates were higher in salinities below 35\% species suggests that they are adapted to the salinity regimes of their habitats, for $G$. aff. venucosa was collected from a place with salinities ranging from 30 to $33 \% \%$, and Gracilaria sp. in a lagoon with average salinity of $46 \%$. Salinities in the Araruama lagoon (RJ) can reach $80 \%$ oo. However, Gracilaria sp. died in salinities above $70 \%$ after one week under our experimental conditions (not shown in our figures). Probably, under natural conditions, exposure to higher salinities occurs only for short periods of time and is not

\section{DISCUSION}

Las especies que fueron estudiadas mostraron tener una amplia tolerancia a variaciones de salinidad bajo condiciones de laboratorio; sin embargo, como puede apreciarse en la Tabla 3, la salinidad interviene significativamente en las tasas de crecimiento de las algas. Los resultados reflejan la distribución natural de las algas. Todas las especies estudiadas, con excepción de Meristiella echinccaupa, pueden ser encontradas en la zona intermareal, por lo tanto éstas están sujetas a períodos variables de emersión y consecuentemente a una variación más amplia de los factores ambientales. Otros autores ya habían llegado a conclusiones similares, desde Biebl (1937).

La eurihalinidad de las especies de Gracilaria ha sido bien documentada por Causey et al. (1946), Stokke (1957), Simonetti 


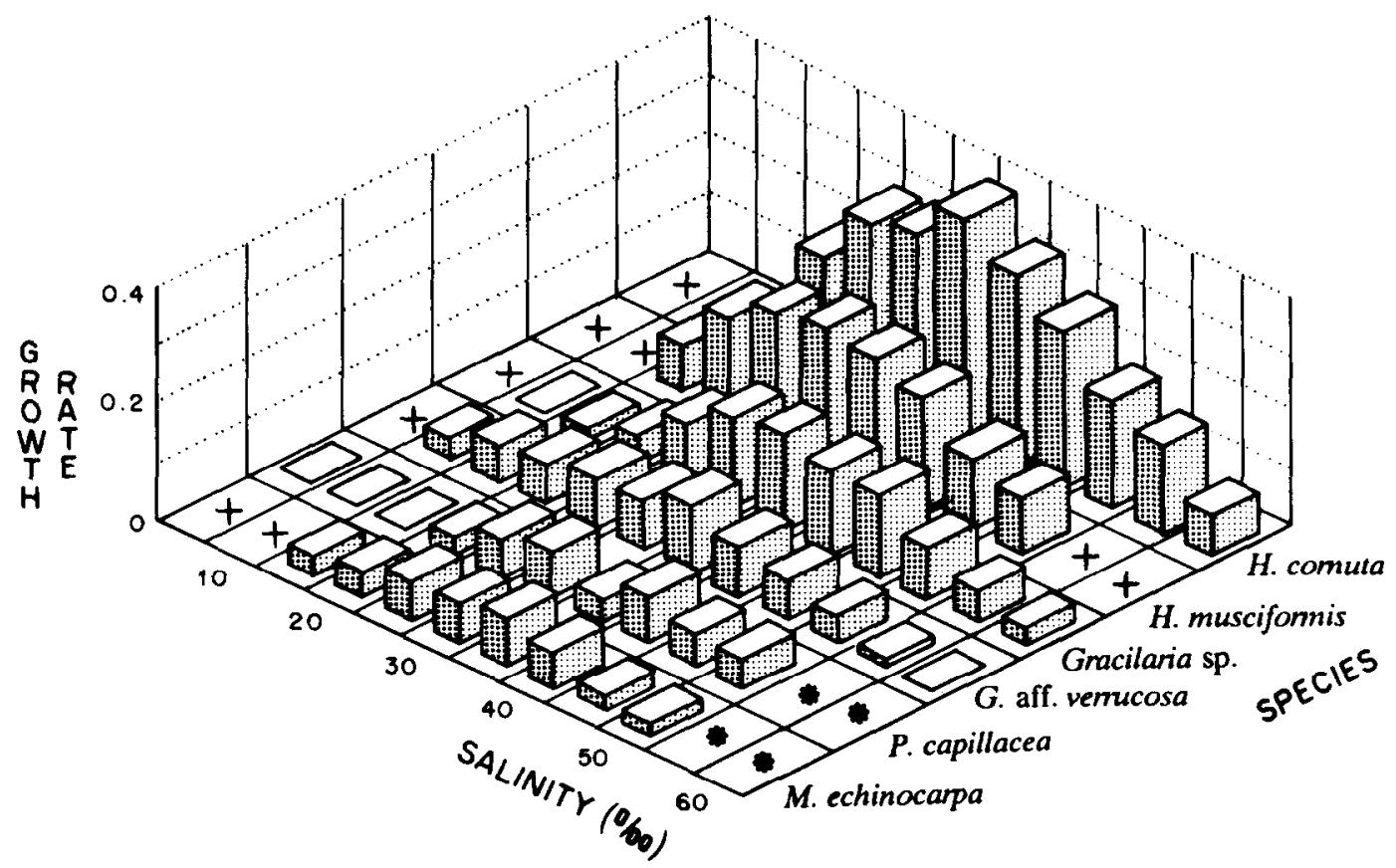

Figure 7. Growth rate $\left(k=\log _{2}\left(W f . W^{-1}\right) \cdot t^{-1}\right)$, where $W f=$ final fresh weight, $W_{0}=$ initial fresh weight, $t=$ time in days, of the species incubated in different salinites; ${ }^{*}$ not tested, + dead plants.

Figura 7. Tasa de crecimiento $\left(k=\log _{2}\left(W f . W o^{-1}\right) \cdot t^{-1}\right)$, donde $W f=$ peso fresco final, $W o=$ peso fresco inicial, $t$ = tiempo en días, de las especies incubadas en diferentes salinidades; * no probado, + plantas muertas.

enough to eliminate the complete populations. Besides, the natural conditions are not the same as in our experiments. The highest values of growth rate of $G$. aff. verrucosa and Gracilaria sp. ( 0.120 and 0.162 respectively) are similar to the ones found for $G$. verncosa by Rueness and Tananger (1984) and Ren et al. (1984). However, Saunders and Lindsay (1979) and Bird (1984) found values lower than ours.

Hypnea species are considered euryhaline. However, in our experiments, Hypnea spp. were the least tolerant to salinity variations. $H$. musciformis and $H$. comuta tolerated salinity variations from 20 to $50 \%$ and from 20 to $60 \%$, respectively. Dawes et al. (1976), studying plants of $H$. muscifomis collected on an exposed shore and a protected estuary in Florida, determined tolerance limits from 15 to $45 \%$. Estuarine plants showed the highest photosynthetic rates in salinities et al. (1970), Muñoz et al. (1984) y Bird y McLachlan (1986). Causey et al. (1946) determinaron el máximo crecimiento de $G$. verrucosa en salinidades de 25 a $35 \%$, y Bird y McLachlan (1986) observaron que el máximo crecimiento para varias especies de Gracilaria se da entre 15 y $38 \%$. Estos resultados están de acuerdo con lo propuesto en este estudio para $G$. aff. vemucosa, la cual presenta su máximo crecimiento en salinidades de 25 a $40 \%$ oo. Gracilaria sp. mostró tasas de crecimiento relativamente más altas en salinidades mayores a $35 \%$, mientras que para $G$. aff. verrucosa las tasas de crecimiento fueron más altas en salinidades por debajo de $35 \%$. El comportamiento de ambas especies sugiere que éstas se adaptan a los regímenes de salinidad de sus habitats, ya que $G$. aff. venucosa fue colectada en un sitio cuya salinidad varía entre 30 y $33 \%$, y Gracilaria sp. se colectó en una laguna cuya salinidad 
Table 2. Exponential growth rate $\left(k=\log _{2}\left(W f . W o^{-1}\right) \cdot t^{-1}\right)$, where $W f=$ final fresh weight, $W o=$ initial fresh weight, $t=t$ time in days; mean \pm standard error $(n=3)$, of the species submitted to different salinities.

Tabla 2. Tasa de crecimiento exponencial $\left(k=\log 2\left(W f . W o^{-1}\right) \cdot t^{-1}\right)$, donde $W f=$ peso fresco final, $W o=$ peso fresco inicial, $t=t$ tempo en días; media \pm error estándar $(n=3)$, de las especies sometidas a diferentes salinidades.

\begin{tabular}{|c|c|c|c|c|c|c|}
\hline \multirow{2}{*}{$\begin{array}{c}S \\
(\% / \infty 0)\end{array}$} & \multicolumn{6}{|c|}{ Species } \\
\hline & $G$. aff. vemucosa & Gracilaria sp. & H. comiuta & H. muscifonnis & M. echinocarpa & P. capillacea \\
\hline 60 & $0.006 \pm 0.001 *$ & $0.024 \pm 0.001 *$ & $0.069 \pm 0.090 *$ & + & - & - \\
\hline 55 & $0.017 \pm 0.002^{*}$ & $0.057 \pm 0.007^{*}$ & $0.150 \pm 0.010^{*}$ & + & - & - \\
\hline 50 & $0.045 \pm 0.004^{*}$ & $0.096 \pm 0.012 *$ & $0.187 \pm 0.014^{*}$ & $0.097 \pm 0.013^{*}$ & $0.019 \pm 0.002^{*}$ & $0.053 \pm 0.013^{*}$ \\
\hline 45 & $0.072 \pm 0.002^{*}$ & $0.140 \pm 0.007 \mathrm{~ns}$ & $0.271 \pm 0.013 *$ & $0.125 \pm 0.013^{*}$ & $0.027 \pm 0.008 *$ & $0.057 \pm 0.006 *$ \\
\hline 40 & $0.093 \pm 0.001 *$ & $0.141 \pm 0.029 \mathrm{~ns}$ & $0.331 \pm 0.026^{*}$ & $0.190 \pm 0.008$ * & $0.061 \pm 0.006 \mathrm{~ns}$ & $0.085 \pm 0.006 \mathrm{~ns}$ \\
\hline 35 & $0.120 \pm 0.004$ & $0.162 \pm 0.008$ & $0.389 \pm 0.011$ & $0.220 \pm 0.005$ & $0.081 \pm 0.014$ & $0.080 \pm 0.024$ \\
\hline 30 & $0.094 \pm 0.003 *$ & $0.154 \pm 0.011 \mathrm{~ns}$ & $0.323 \pm 0.032^{*}$ & $0.232 \pm 0.004 \mathrm{~ns}$ & $0.071 \pm 0.011 \mathrm{~ns}$ & $0.075 \pm 0.016 \mathrm{~ns}$ \\
\hline 25 & $0.093 \pm 0.004 *$ & $0.106 \pm 0.004^{*}$ & $0.301 \pm 0.033^{*}$ & $0.218 \pm 0.002 \mathrm{~ns}$ & $0.068 \pm 0.007 \mathrm{~ns}$ & $0.060 \pm 0.005 \mathrm{~ns}$ \\
\hline 20 & $0.072 \pm 0.002 *$ & $0.044 \pm 0.010^{*}$ & $0.200 \pm 0.013^{*}$ & $0.170 \pm 0.002^{*}$ & $0.045 \pm 0.003^{*}$ & $0.024 \pm 0.004^{*}$ \\
\hline 15 & $0.059 \pm 0.009 *$ & $0.023 \pm 0.009 *$ & + & + & $0.030 \pm 0.013^{*}$ & $0.009 \pm 0.006^{*}$ \\
\hline 10 & $0.037 \pm 0.006 *$ & $0.009 \pm 0.005^{*}$ & + & + & + & $-0.004 \pm 0.004^{*}$ \\
\hline 05 & + & + & + & + & + & $-0.004 \pm 0.006^{*}$ \\
\hline
\end{tabular}

- = not tested; + = lethal salinities; * or ns = significant or not significant difference at $5 \%$ level between each mean compared with the one obtained on salinity of $35 \%$, respectively. 
Table 3. Percentage of water content $\left(\%=(F W-D W) . F W^{-1} \times 100 \%\right)$, mean \pm standard error $(n=3)$, of plants on different salinities at the end of the experiments $(20,28$ and 35 days to $H$. comuta, Gracilaria spp. and $M$. echinocarpa respectively). $F W=$ fresh weight, $D W=$ dry weight.

Tabla 3. Porcentaje del contenido de agua $\left(\%=(F W-D W) . F W^{-1} \times 100 \%\right)$, medio \pm error estándar $(n=3)$, de plantas en diferentes salinidades al final de los experimentos $(20,28$ y 35 días para $H$. comuta, Gracilaria spp. y $M$. echinocarpa respectivamente). $F W=$ peso fresco, $D W=$ peso seco.

\begin{tabular}{clllc}
\hline \multirow{2}{*}{$\begin{array}{c}\mathrm{S} \\
(\%) 0\end{array}$} & \multicolumn{3}{c}{ Species } \\
\cline { 2 - 5 } & G. aff. vemucosa & Gracilaria sp. & H. comuta & M. echinocaipa \\
\hline 60 & $72.9 \pm 3.5^{*}$ & $80.6 \pm 0.4^{*}$ & $82.5 \pm 6.4^{*}$ & - \\
55 & $66.7 \pm 0.1^{*}$ & $84.1 \pm 0.6^{*}$ & $82.4 \pm 1.4^{*}$ & - \\
50 & $73.7 \pm 2.7^{*}$ & $87.2 \pm 0.1^{*}$ & $86.0 \pm 0.1 \mathrm{~ns}$ & $82.6 \pm 0.7^{*}$ \\
45 & $80.0 \pm 1.8^{*}$ & $87.4 \pm 0.1^{*}$ & $89.0 \pm 1.4 \mathrm{~ns}$ & $87.0 \pm 1.2^{*}$ \\
40 & $81.9 \pm 1.3^{*}$ & $85.8 \pm 1.3 \mathrm{~ns}$ & $92.5 \pm 0.7 \mathrm{~ns}$ & $90.2 \pm 0.2 \mathrm{~ns}$ \\
35 & $87.1 \pm 0.8^{*}$ & $85.7 \pm 0.2^{*}$ & $90.0 \pm 0.1$ & $89.6 \pm 0.8$ \\
30 & $83.3 \pm 2.3^{\mathrm{ns}}$ & $84.9 \pm 0.6 \mathrm{~ns}$ & $92.5 \pm 0.7 \mathrm{~ns}$ & $89.0 \pm 1.3 \mathrm{~ns}$ \\
25 & $81.7 \pm 0.5^{*}$ & $79.9 \pm 1.1^{*}$ & $91.0 \pm 1.4^{*}$ & $89.3 \pm 0.4^{*}$ \\
20 & $80.0 \pm 0.1^{*}$ & $79.2 \pm 1.2^{*}$ & $83.0 \pm 1.4^{*}$ & $87.7 \pm 0.5^{*}$ \\
15 & $80.5 \pm 0.8^{*}$ & $79.0 \pm 1.2^{*}$ & + & $88.0 \pm 0.5^{*}$ \\
10 & $86.1 \pm 0.8$ & $83.2 \pm 0.1^{*}$ & + & + \\
\hline
\end{tabular}

- = not tested; $+=$ lethal salinities; ${ }^{*}$ or $\mathrm{ns}=$ significant or not significant difference at $5 \%$ level between each mean compared with the one obtained on salinity of $35 \%$, respectively.

from 10 to $40 \%$ oo; on the other hand, for rocky shore plants the optimum salinity was $20 \%$. The higher growth rates of $H$. comuta occurred in higher salinities, suggesting adaptation to the regimes of the lagoon. Comparing the growth rates of all the species studied, $H$. comuta and $H$. musciformis presented the highest growth rates $(0.389$ and 0.269 respectively), values higher than the ones observed by Friedlander and Zelikovitch (1984) for the same species.

Meristiella echinocarpa did not grow well in salinities below 25 and above $40 \%$, which is in accordance with its infralittoral distribution, being a species that is exposed for brief periods only in exceptionally low tides.

The results we obtained for Pterocladia capillacea confirm the observations of Santelices (1978), in Hawaii, for the same species. $P$. capillacea presented the lowest growth rates observed among the species studied. The values obtained are higher than the ones found by Santelices $(1976,1978)$ and Oliveira and Yoneshigue (1986). promedio es de $46 \%$. Las salinidades en la laguna Araruama (RJ) pueden llegar a 80\% Sin embargo, Gracilaria sp. murió en salinidades por arriba de $70 \%$ después de estar sometida a condiciones experimentales por una semana (no se muestra en las figuras). Es probable que bajo condiciones naturales la exposición a salinidades mayores ocurra sólo por períodos cortos de tiempo, los cuales no son lo suficientemente drásticos para eliminar por completo a las poblaciones. Además, las condiciones naturales no son las mismas que en nuestros experimentos. Los valores más altos en la tasa de crecimiento de $G$. aff. vernucosa y Gracilaria sp. $(0.120$ y 0.162 respectivamente) son similares a los encontrados por Rueness y Tananger (1984) y Ren et al. (1984) para G. vernucosa; sin embargo, Saunders y Lindsay (1979) y Bird (1984) encontraron valores más bajos que los que se presentan en este estudio.

Las especies de Hypnea son consideradas eurihalinas. Sin embargo, en nuestros experimentos, éstas fueron menos tolerantes a las variaciones de salinidad. $H$. muscifomis y 

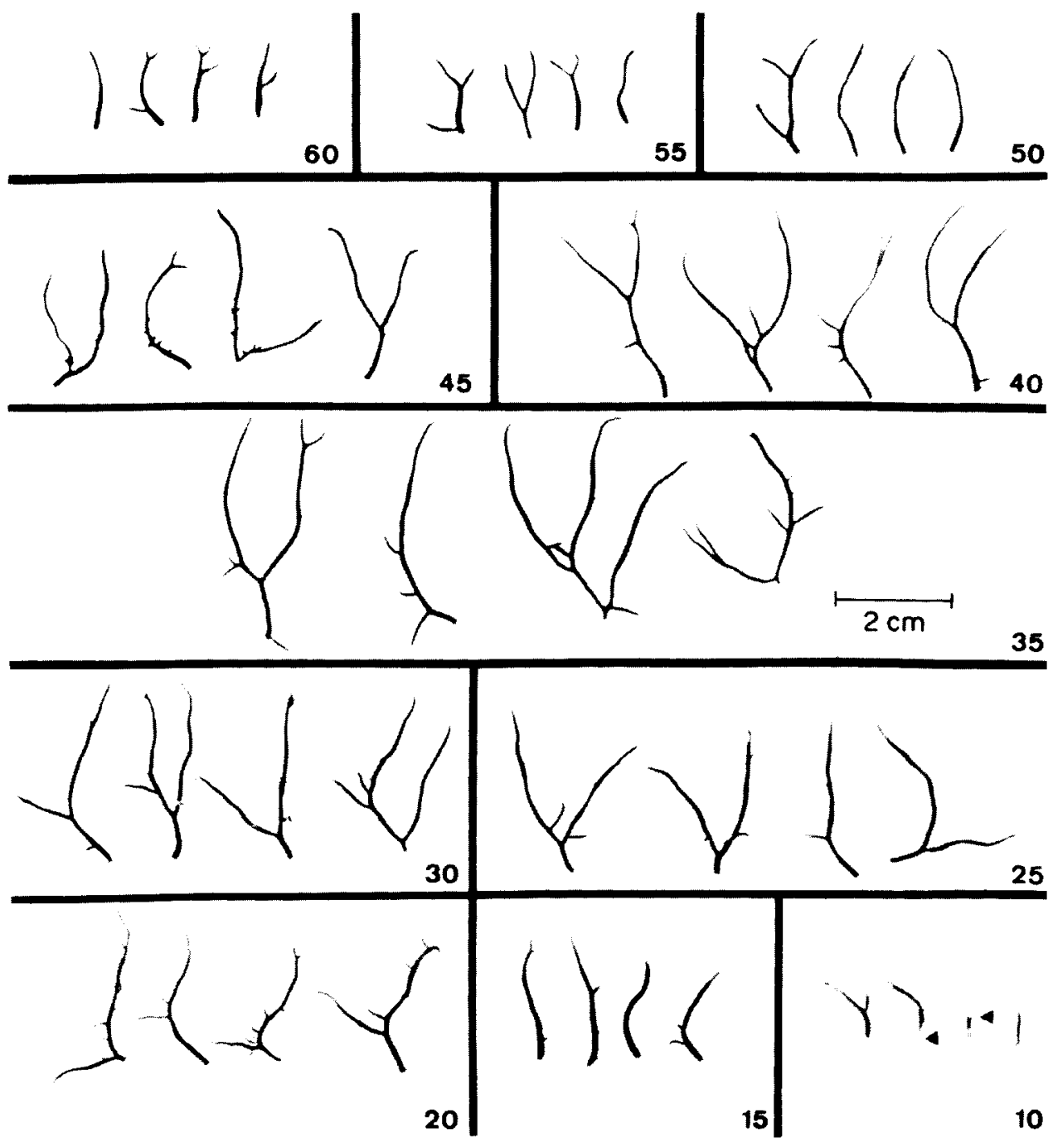

Figure 8. Gracilaria aff. vemucosa. Plants incubated in different salinities after 28 days. Necrotic zones are indicated by arrowheads. The numbers on the right indicate the salinity tested.

Figura 8. Gracilaria aff. venucosa. Plantas incubadas en diferentes salinidades después de 28 días. Las flechas indican las zonas necróticas. Los números a la derecha indican la salinidad usada.

The relation between percentage of water content and salinity is not clear, except for an inverse relation observed in salinities above $40 \%$ for Gracilaria aff. vemucosa,
$H$. comuta toleraron variaciones de salinidad de 20 a $50 \%$ yo ye 20 a $60 \%$, respectivamente. En un trabajo presentado por Dawes et al. (1976) se estudiaron plantas de $H$. 

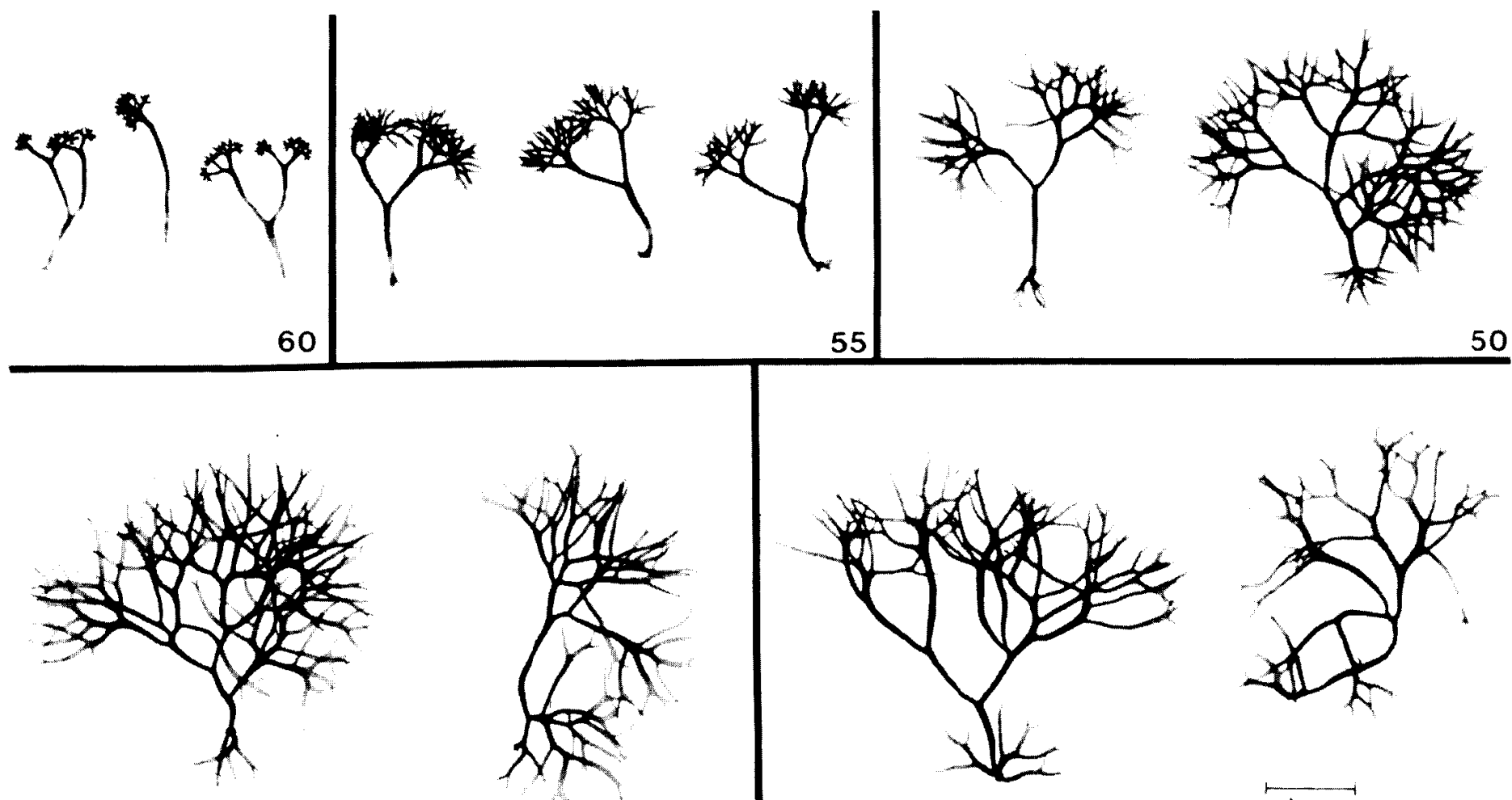

$1 \mathrm{~cm}$

Figure 9. Gracilaria sp. Plants incubated in different salinities after 28 days. Necrotic zones are indicated by arrowheads. The numbers on the right indicate the salinities tested.

Figura 9. Gracilaria sp. Plantas incubadas en diferentes salinidades después de 28 días. Las flechas indican las zonas necróticas. Los números a la derecha indican la salinidad usada. 


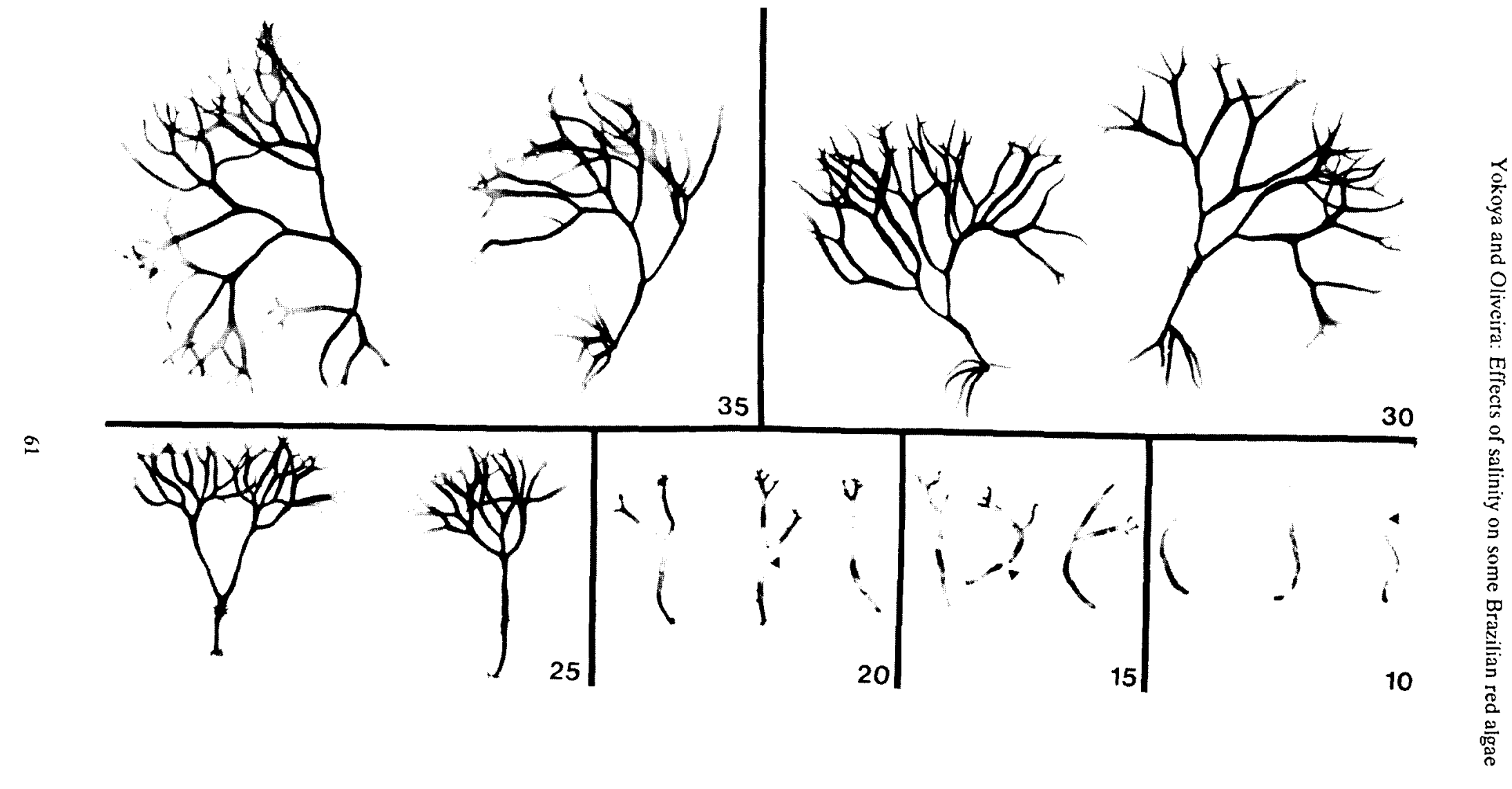

Fig. 9 (Cont.) 
Hypnea comuta and Meristiella echinocarpa, and above $50 \%$ for Gracilaria sp. (Table 3).

We conclude that the species studied have a rapid osmotic adaptation, being able to withstand the salinity variation in their habitats. None of them, however, can thrive in the lower salinities found in estuaries and mangals, places often considered for mariculture. Our results show that the six species can be cultivated in localities with salinities ranging from 25 to $40 \% \%$, and up to $60 \%$ oo for Hypnea comuta from Araruama lagoon, which is the case in some ponds utilized for shrimp growth in the northeast of Brazil.

\section{ACKNOWLEDGEMENTS}

We thank John A. West, Edison J. de Paula and Julio A. Vásquez for a critical reading of the manuscript. This work was supported partially by a Master grant from FAPESP to N.S.Y. (Proc. No. 85/1313-0).

\section{LITERATURE CITED}

Biebl, R. (1937). Zur protoplasmatischen anatomie der rotalgen. Protoplasma, 28: 562-581.

Bird, K.T. (1984). Seasonal variation in protein: carbohydrate ratios in a subtropical estuarine alga, Gracilaria vemicosa, and the determination of nitrogen limitation status using these ratios. Bot. Mar., 27: 111-115.

Bird, C.J. and McLachlan, J. (1986). The effect of salinity on distribution of species of Gracilaria Grev. (Rhodophyta, Gigartinales): an experimental assessment. Bot. Mar., 29: 231-238.

Bird, N.L., Chen, L.C.M. and McLachlan, J. (1979). Effects of temperature, light and salinity on growth in culture of Chondrus crispus, Furcellaria lumbricalis, Gracilaria tikvahiae (Gigartinales, Rhodophyta) and Fucus serratus (Fucales, Phaeophyta). Bot. Mar., 22: 521-527.

Burns, R.L. and Mathieson, C. (1972). Ecological studies of economic red algae. II. Culture studies of Chondrus crispus Stackhouse and Gigartina stellata (Stackhouse) Batters. J. Exp. Mar. Biol. Ecol., 8: 1-6.

Causey, N.J., Prythetch, J., McLaskill, H.H. and Wolf, F. (1946). Influence of envi- muscifomis las cuales fueron colectadas en una playa expuesta y en un estuario protegido de Florida (EUA), en donde los límites de tolerancia variaron de 15 a $45 \%$. Los ejemplares estuarinos mostraron las más altas tasas fotosintéticas en salinidades que van de 10 a $40 \%$ oo; por otro lado, para los ejemplares de la playa rocosa la salinidad óptima fue de $20 \%$. Las más altas tasas de crecimiento para $H$. comuta ocurrieron en altas salinidades, sugiriendo así una adaptación a los diferentes regímenes de la laguna. Comparando las tasas de crecimiento de todas las especies estudiadas, $H$. comuta y $H$. musciformis presentaron las más altas tasas de crecimiento (0.389 y 0.269 respectivamente). Estos valores son mayores a los reportados por Friedlander y Zelikovitch (1984) para las mismas especies.

En el caso de Meristiella echinocarpa, ésta no se desarrolló bien en salinidades por debajo de $25 \%$ y por arriba de $40 \%$, lo cual va de acuerdo a su distribución en el infralitoral, puesto que son especies que están expuestas por breves períodos y sólo durante mareas excepcionalmente bajas.

Los resultados obtenidos en este estudio para Pterocladia capillacea confirman las observaciones hechas por Santelices (1978), en Hawaii, para las mismas especies. $P$. capillacea presentó las más bajas tasas de crecimiento observadas en todas las especies estudiadas. Los valores obtenidos son mayores que los encontrados por Santelices $(1976,1978)$ y Oliveira y Yoneshigue (1986).

La relación que existe entre los porcentajes de contenido de agua y la salinidad no es clara, con excepción de una relación inversa observada en salinidades por encima de 40\% para Gracilaria aff. verrucosa, Hypnea comuta y Meristiella echinocarpa, y por encima de 50\% para Gracilaria sp. (Tabla 3).

Se concluye que las especies estudiadas tienen una rápida adaptación osmótica, que les permite tolerar variación de la salinidad en sus habitats. Ninguna de éstas, sin embargo, puede crecer en las salinidades más bajas encontradas en estuarios y manglares, lugares que actualmente son considerados para la maricultura. Nuestros resultados muestran que las seis especies pueden ser cultivadas en localidades con salinidades entre 25 y $40 \% \%$, y hasta $60 \%$ para Hypnea comuta, proveniente de la laguna Araruama, como es el caso 
ronmental factors upon the growth of Gracilaria confervoides. Bull. Duke Univ. Mar. Stn., 3: 19-24.

Conover, J.T. (1964). The ecology, seasonal periodicity and distribution of benthic plants in some Texas lagoons. Bot. Mar., 7: 5-41.

Dawes, C.J., Moon, R. and La Claire, J. (1976). Photosynthetic responses of the red alga, Hypnea muscifomis (Wulfen) Lamouroux (Gigartinales). Bull. Mar. Sci., 26: 467-473.

Druehl, L.D. (1967). Vertical distribution of some benthic marine algae in a British Columbia inlet, as related to some environmental factors. J. Fish. Res. Bd. Canada, 24: 33-46.

Friedlander, M. and Zelikovitch, N. (1984). Growth rates, phycocoloid yield and quality of the red seaweeds Gracilaria tenuifrons, Pterocladia capillacea, Hypnea muscifomis, and Hypnea comuta in field studies in Israel. Aquaculture, 40: 57-66.

Gessner, F. and Schramm, W. (1971). Salinity. Plants. In: $O$. Kinne (ed.), Marine Ecology. London, Wiley - Interscience, Vol. 1, pt. 2, pp. 705-820.

Khfaji, A.K. and Norton, T.A. (1979). The effects of salinity on the distribution of Fucus ceranoides. Estuarine Coastal Mar. Sci., 8: 433-439.

King, R.J. and Wheeler, M.D. (1985). Composition and geographic distribution of mangrove macroalgal communities in New South Wales. Proc. Linn. Soc. N.S.W., 108: 97-117.

Mathieson, A.C. and Burns, R.L. (1975). Ecological studies of economic red algae. $V$. Growth and reproduction of natural and harvested populations of Chondrus crispus (Stackhouse) in New Hampshire. J. Exp. Mar. Biol. Ecol., 17: 137-156.

McLachlan, J. (1973). Growth media - marine. In: J.R. Stein (ed.), Handbook of Phycological Methods. Culture Methods and Growth Measurements. Cambriuge Univ. Press, pp. 25-51.

Munda, 1.M. (1978). Salinity dependent distribution of benthic algae in estuarine areas of Icelandic fjords. Bot. Mar., 21: 451-468. en algunas lagunas que han sido utilizadas para el crecimiento de camarón en el noreste de Brasil.

\section{AGRADECIMIENTOS}

Agradecemosa John A. West, Edison J. de Paula y Julio A. Vásquez sus comentarios al manuscrito. Este trabajo fue apoyado en parte por un "Master grant" de FAPESP a N.S.Y. (Proc. No. 85/1313-0).

Traducido al español por Ana Luz Quintanilla M.

Muñoz, M.A., Romo, H. y Alveal, K. (1984). Efecto de la salinidad en el crecimiento de tetrasporofitos juveniles de Gracilnia vemucosa (Hudson) Papenfuss (Rhodophyta, Gigartinales). Gayana, 41: 119-125.

Nygren, A. (1970). Effect of salinity on the growth of Dasya pedicellata. Helgolander Meeresunters, 20: 126-129.

Ogata, E. and Schramm, W. (1971). Some observations on the influence of salinity on growth and photosynthesis in Porphyra umbilicalis. Mar. Biol., 10: 70-76.

Oliveira, E.C. (1984). Brazilian mangal vegetation with special emphasis on the seaweeds. In: F.D. Por and I. Dor (eds.), Hydrobiology of Mangal. Dr. W. Junk Publishers, The Hague, pp. 55-65.

Oliveira, E.C. and Yoneshigue, Y. (1986). Cultivation of the red alga Pterocladia capillacea in tanks. Proc. Int. Seaweed Symp., 12: 81 .

Reed, R.H. and Russel, G. (1978). Salinity fluctuations and their influence on "bottle brush" morphogenesis in Enteromorpha intestinales. Br. Phycol. J., 13: 149-153.

Ren, G-Z, Wang, J.C. and Chen, M.Q. (1984). Cultivation of Gracilaria by means of low rafts. Proc. Int. Seaweed Symp., 11: 72-76.

Rueness, J. and Tananger, T. (1984). Growth in culture of four red algae from Norway with potential for mariculture. Proc. Int. Seaweed Symp., 11: 303-307. 
Santelices, B. (1976). Nota sobre cultivo masivo de algunas especies de Gelidiales (Rhodophyta). Rev. Biol. Mar., 16: 27-33.

Santelices, B. (1978). Multiple interaction of factors in the distribution of some Hawaiian Gelidiales (Rhodophyta). Pacif. Sci., Honolulu, 32: 110-147.

Saunders, R.G. and Lindsay, J.G. (1979). Growth and enhancement of the agarophyte Gracilaria (Florideophyceae). Proc. Int. Seaweed Symp., 9: 249-255.

Simonetti, G., Giaccone, G. and Pignatti, S. (1970). The seaweed Gracilaria confervoides, an important object for autoecologic and cultivation research in the northern Adriatic Sea. Helgolander Meeresunters, 20: 89-96.
Stokke, K. (1957). The red alga Gracilaria vernicosa in Norway. Nytt Magasin for Bot. Oslo, 5: 101-111.

Sundene, O. (1953). The algal vegetation of Oslofjord; Norske Vidensk Akad. Oslo, Mat. - Naturv. Klasse 1953, No. 2. Apud: L.D. Druehl, 1981. Geographical distribution. In: C.S. Lobban and M.J. Wynne (eds.), The Biology of Seaweeds. Blackwell Scientific Publ., pp. 680-725.

Zablackis, E. (1987). The effect of salinity on growth rate and branch morphology in tank cultivated Grateloupia filicina (Rhodophyta) in Hawaii. Aquat. Bot., 27: 187-193. 